\title{
Public Awareness towards Sustainable Transportation in Shah Alam, Malaysia
}

\author{
Na'asah Nasrudin ${ }^{1}$, Harifah Mohd Noor², Yusfida Ayu Abdullah ${ }^{1}$ \\ ${ }^{1}$ Faculty of Architecure, Planning and Surveying, \\ Universiti Teknologi MARA, 40450, Shah Alam, Selangor, Malaysia \\ ${ }^{2}$ Faculty of Social Sciences, Universiti Malaysia Sabah, 88999, Kota Kinabalu, Sabah, Malaysia \\ naasah76@gmail.com.my
}

\begin{abstract}
This paper studied the awareness of an urban population to use sustainable vehicles and their readiness to reduce car usage. Data were collected through a survey of 384 vehicle users in Shah Alam, Selangor. Results suggested that the majority were not ready to consider cycling and walking as alternatives. About to environmental awareness, the majority showed their awareness of the dangers of motor vehicles towards the environment. However, they refused to use more sustainable mode oftravelling. Among other reasons provided as "refusal" regarding of sustainable vehicles,applicationwas hot weather, surrounding safety factor and inefficient public transport services.

Keywords: Sustainable vehicles; environmental awareness, travel behavior

eISSN 2398-4295 @ 2018. The Authors. Published for AMER ABRA cE-Bs by e-International Publishing House, Ltd., UK. This is an open-access article under the CC BY-NC-ND license (http://creativecommons.org/licenses/bync-nd/4.0/). Peer-review under responsibility of AMER (Association of Malaysian Environment-Behaviour Researchers), ABRA (Association of Behavioural Researchers on Asians) and cE-Bs (Centre for EnvironmentBehaviour Studies), Faculty of Architecture, Planning \& Surveying, Universiti Teknologi MARA, Malaysia.

http://dx.doi.org/10.21834/ajbes.v3i11.109
\end{abstract}




\subsection{Introduction}

In the last decade, mobility level has increased significantly in the urban areas of many countries. This scenario has raised concerns about increasing car usage and consequent congestion and pollution effects. The current nature of transport, and the need to go through the changes in society and lifestyle patterns that generate a variety of travel needs, cause most people to be very dependent on car travel (Anable, 2005). Cars are seen as convenient, reliable, secure, and able to provide access to more destinations than public transport. These factors influence the desire of residents to own a car (Hiscock et al., 2002).

In Malaysia, cars showed their highest growth rate between 1991 and 2009, with an average annual growth rate of about $9 \%$, followed by two-wheelers $(7 \%)$. Meanwhile, public transport (i.e., buses, taxis, and rental cars) registered a much lower growth rate of about $5 \%$ during this same period. In 1991 , the two modes had a total share of about $89 \%$ of the entire vehicular population. Of these, cars and two-wheelers accounted for $37 \%$ and $52 \%$, respectively. In 2009, the total modal share of cars and two-wheelers increased to $92 \%$. However, two-wheelers, which had a higher share than cars in 1991, slowly lost their share to cars between 1991 and 2009. If this trend continues, cars are expected to become the most dominant mode of transport in Malaysia in the coming years (Ministry of Transport Malaysia, 2010).

\subsection{Literature Review}

Factors that have been used in research on car usage through behaviour theory include concern for the environment, value orientation, and relationship to a pro-environmental attitude (Van Vugt et al., 1995; Grob, 1997; E. Garling et al., 1998; Nilsson and Kuller, 2000).

The assumption underlying this approach is that critical environmental problems increase, ease, or allow the strategy to reduce car usage through a pro-environmental attitude with an increased scope (Nilsson and Kuller, 2000). The emphasis is to explore the factors that propel or predispose an individual to behave in a more pro-environment manner (Stern, 2000).

Two car-usage models were designed, known as practical and attitude models. These models were first made to capture the main factor groups identified as important in configuring the individual's relationship with the car; that is, individuals have practical versions of a negative environmental and social impact of car usage. Second, the readiness or intention to change car usage can be very relevant, given the changes to increased automobile use, but perhaps even more importantly, change is dependent on specific factors, such as road capacity, government regulations, urban planning for non-motorized vehicles, as well as public transit users.

A review by Vugt et al. (1995) showed that more altruistic individuals are more likely to express a willingness to reduce car usage; whereas, ego-oriented individuals express no concern over significant consequences. These results indicate some support for the influence of value orientation on the willingness to participate in environmental behaviours, where more 
altruistic individuals are more likely to develop the dilemma surrounding car usage in terms of the collective well-being (Merritt Polk, 2004).

A large support for measures to reduce car usage and increased car consumption criticism will help to increase an individual's willingness to reduce car usage. Political proposals to reduce or eliminate environmental impacts also show significant effects on the willingness to change car usage. Hence, the development and improvement of public transport should be increased in line with efforts to reduce car usage.

\subsection{Methodology}

A total of 384 respondents were selected for this survey, as a sample representing the 36 sections of Shah Alam by using stratified random sampling method. Selected of the sample was calculated based on the total population which is of 336590 peoples, with $95 \%$ degree of confidence, and $5 \%$ of the margin of error. Distribution of the questionnaire were made from house to the house and also approaching respondent at the recreation center and shopping centers selected for each section. Respondents were provided with a survey form, with several sub-item tests, to gauge their level of car usage. The identified variables were as follows:

- $\quad$ The number of cars owned and the number of licenses held in a family

- The emotion and perception of owning and driving a car

- The level of readiness to reduce car usage, to walk or cycle, and to use public transport (bus, taxi and commuter train).

All of these variables were derived from the respondents to identify their extent of car dependency. Respondents were also tested for their level of awareness to the importance of environmental conservation, to see how much they were aware of environmental pollution, given their car usage.

\subsection{Results and Discussions}

\section{Car ownership and driving licenses held in a family}

Table 1 shows that the average number of vehicles owned per family was two, and the average number of a car driving licenses belonging to a family was three. These numbers show that virtually every family has a car, and every family has more than one member with a driving license. 
Table 1. Number of cars and driving licenses held in a family

\begin{tabular}{|ccc|lcc|}
\hline $\begin{array}{l}\text { Number of } \\
\text { cars } \\
\text { owned in } \\
\text { the family }\end{array}$ & Total & Percentage (\%) & $\begin{array}{l}\text { Number of } \\
\text { driving } \\
\text { licenses } \\
\text { held in the } \\
\text { family }\end{array}$ & & $\begin{array}{c}\text { Total } \\
(\%)\end{array}$ \\
\hline 0 & 24 & 6.3 & 1 & 8 & 2.1 \\
1 & 131 & 34.1 & 2 & 54 & 14.1 \\
2 & 159 & 41.4 & 3 & 136 & 35.4 \\
3 & 36 & 9.4 & 4 & 88 & 22.9 \\
4 & 22 & 5.7 & 5 & 52 & 13.5 \\
5 & 7 & 1.8 & 6 & 27 & 7.0 \\
6 & 3 & 0.8 & 7 & 14 & 3.6 \\
7 & 2 & 0.5 & 8 & 4 & 1.0 \\
\hline Total & 384 & 100 & 9 & 1 & 0.3 \\
\hline
\end{tabular}

\section{Emotions and perceptions toward cars}

In the current study, when asked how they felt while driving their cars, the majority of the respondents provided positive feedback. Most considered driving a car as "relaxing" and "safe." They also stated that driving a car was practical and gave them freedom.

\begin{tabular}{|c|c|c|}
\hline Statements & Total & Percentage \\
\hline Freedom & 108 & 28.1 \\
\hline Practicality & 110 & 28.6 \\
\hline Relaxing & 134 & 34.9 \\
\hline Safety & 132 & 34.4 \\
\hline Boredom & 16 & 4.2 \\
\hline Stressful & 13 & 3.4 \\
\hline Tiring & 25 & 6.5 \\
\hline Troublesome & 11 & 0.3 \\
\hline
\end{tabular}

Hiscock et al. (2002) conducted interviews with car owners and non-car owners in Scotland, to investigate the psycho-social benefits to people that seem to originate from their cars. They found that a car is seen as something that provides security from unwanted people and events, as well as providing autonomy for its convenience, reliability, and capability to provide access to more destinations than public transport.

\section{Willingness to reduce car usage}

Table 3 shows analysis results using the Chi-Square method. The analysis indicated a ChiSquare value of 50.411 , which is significant at the 0.05 level $(p=0.001)$. A significant association was observed between the level of willingness to reduce car usage and the monthly income of respondents. Cramer's $V$ value showed that monthly income had a moderate relationship with the level of willingness to reduce car usage $(V=0.362)$. 
Nasrudin, N., et.al. / Asian Journal of Behavioural Studies (AjBeS), 3(11) May / Jun 2018 (p.137-146)

Table 3. Level of willingness to reduce car usage by income

\begin{tabular}{|c|c|c|c|c|c|c|c|c|}
\hline \multirow[t]{4}{*}{ Monthly income } & \multicolumn{7}{|c|}{ Willingness to reduce car usage } & \multirow[t]{4}{*}{ Total } \\
\hline & \multirow{3}{*}{$\begin{array}{l}\text { Extremely } \\
\text { not ready } \\
1\end{array}$} & & & & & \multicolumn{2}{|c|}{ Extremely } & \\
\hline & & & & & & & & \\
\hline & & 2 & 3 & 4 & 5 & 6 & 7 & \\
\hline$<\mathrm{RM} 499$ & 8 & 11 & 22 & 19 & 17 & 14 & 11 & 102 \\
\hline RM 500-RM 1,500 & 4 & 9 & 20 & 22 & 9 & 3 & 11 & 78 \\
\hline RM 1,501-RM 3,500 & 16 & 22 & 34 & 22 & 16 & 6 & 6 & 122 \\
\hline \multirow{2}{*}{$\begin{array}{l}\text { RM 3,501-RM 5,500 } \\
>\text { RM 5,501 }\end{array}$} & 4 & 10 & 19 & 8 & 8 & 2 & 4 & 55 \\
\hline & 9 & 7 & 5 & 4 & 1 & 1 & 0 & 27 \\
\hline Total & 41 & 59 & 100 & 75 & 51 & 26 & 32 & 384 \\
\hline
\end{tabular}

\section{Willingness to Switch to Walking or Cycling}

The current study found that the majority are not willing to cycle or walk as alternatives to using a motor vehicle. The unwillingness level had a mean of 3:33 and a standard deviation of 1.892 .

Table 4. Level of willingness to switch to walking or cycling

\begin{tabular}{|c|c|c|c|c|}
\hline $\mathrm{N}$ & Minimum & Maximum & Mean & Std. Deviation \\
\hline 384 & $\begin{array}{c}1 \\
\text { (extremely not } \\
\text { ready) }\end{array}$ & $\begin{array}{c}7 \\
\text { (extremely } \\
\text { ready) }\end{array}$ & 3.33 & 1.892 \\
\hline
\end{tabular}

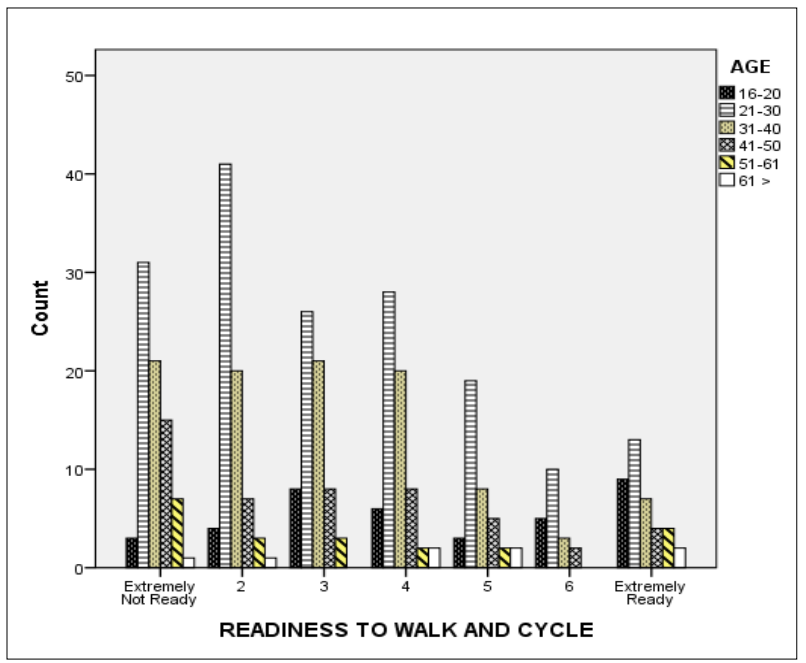

Figure 1. Willingness to switch to walking or cycling by age 
Many previous studies have revealed the relationship between environmental concern and age. In general, younger generations tend to be more concerned about environmental quality than older generations. The extensive literature survey of Van Liere and Dunlap (1981) also stated age as a dominant factor in determining the degree of environmental concern. In these studies, attitudinal changes, due to the ageing process, or "age-effects," are explained based on the changing views of individuals as their role in society changes with age. However, recently, environmental issues have been viewed as a "threat" to the existing social order. Hence, younger generations are considered more open to environmental issues than older generations. In this study, the results show the opposite, where a younger age group (21-30 years old) recorded the highest result on the second level of being not ready to walk or cycle instead of using a car. However, this group also recorded the highest number of respondents that were extremely ready to walk or cycle (refer Fig.1).

\section{Willingness to Switch to Use Public Transport}

This current study examined the level of willingness to use public transport by gender. Table 5 shows the analysis results indicated a Chi Square value of 12.861 , which is significant at the 0.05 level $(p=0.045)$. A significant association was observed between the level of willingness to use public transport and the gender of respondents. Male respondents were shown to be more "extremely not ready" to use public transport compared to females.

Table 5 showed results that were similar to previous studies, proving that women are more pro-environment than men. Polk $(2003,2004)$, in travel behaviour studies in Sweden in 1996, found a significant relationship between sustainable travel patterns and gender. Women were found to be; more willing to reduce their car usage, more positive towards reducing the environmental impact of travel modes, and more positive towards ecological issues than men. Polk concluded that researchers must consider gender as a factor in attitudinal research on car usage. Differences in travel behaviour due to gender have been a significant factor in many papers, with women recognized as being more likely to adopt sustainable travel behaviours than men (Curtis and Perkins, 2006).

Table 5. Level of willingness to switch to use public transport by gender

\begin{tabular}{|c|c|c|c|c|c|c|c|c|}
\hline \multirow[t]{3}{*}{ Gender } & \multicolumn{7}{|c|}{ Willingness to use public transport } & \multirow[t]{3}{*}{ Total } \\
\hline & \multirow{2}{*}{$\begin{array}{c}\text { Extremely } \\
\text { not ready } \\
l\end{array}$} & 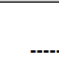 & $\ldots$ & ---- & ------ & ----- & \multirow{2}{*}{$\begin{array}{c}\text { Extremely } \\
\text { ready } \\
7\end{array}$} & \\
\hline & & 2 & 3 & 4 & 5 & 6 & & \\
\hline \multirow[t]{2}{*}{ Male } & 27 & 14 & 51 & 42 & 56 & 26 & 9 & 225 \\
\hline & $12.0 \%$ & $6.2 \%$ & $22.7 \%$ & $18.7 \%$ & $24.9 \%$ & $11.6 \%$ & $4.0 \%$ & $100 \%$ \\
\hline \multirow[t]{2}{*}{ Female } & 14 & 15 & 27 & 39 & 34 & 13 & 17 & 159 \\
\hline & $8.8 \%$ & $9.4 \%$ & $17.0 \%$ & $24.5 \%$ & $21.4 \%$ & $8.2 \%$ & $10.7 \%$ & $100 \%$ \\
\hline \multirow[t]{2}{*}{ Total } & 41 & 29 & 78 & 81 & 90 & 39 & 26 & 384 \\
\hline & $10.7 \%$ & $7.6 \%$ & $20.3 \%$ & $21.1 \%$ & $23.4 \%$ & $10.2 \%$ & $6.8 \%$ & $100 \%$ \\
\hline
\end{tabular}


Table 6. Level of willingness to switch to using public transport by monthly income

\begin{tabular}{|c|c|c|c|c|c|c|c|c|}
\hline \multirow[t]{3}{*}{ Monthly income } & \multicolumn{7}{|c|}{ Willingness to switch to use public transport } & \multirow[t]{3}{*}{ Total } \\
\hline & \multirow{2}{*}{$\begin{array}{l}\text { Extremely } \\
\text { not ready } \\
1\end{array}$} & & & & & \multicolumn{2}{|c|}{$\begin{array}{c}\text { Extremely } \\
--\cdot-\text { ready }\end{array}$} & \\
\hline & & 2 & 3 & 4 & 5 & 6 & 7 & \\
\hline$<$ RM 499 & 9 & 8 & 22 & 22 & 24 & 9 & 8 & 102 \\
\hline RM 500-RM1,500 & 6 & 2 & 14 & 21 & 17 & 9 & 9 & 78 \\
\hline RM 1,501-RM3,500 & 10 & 11 & 27 & 29 & 26 & 11 & 8 & 122 \\
\hline RM3,501-RM5,500 & 3 & 7 & 13 & 5 & 18 & 8 & 1 & \\
\hline$>\mathrm{RM} 5,501$ & 13 & 1 & 2 & 4 & 5 & 2 & 0 & 52 \\
\hline Total & 41 & 29 & 78 & 81 & 90 & 39 & 26 & 384 \\
\hline
\end{tabular}

Analysis using the Chi Square method revealed a Chi Square value of 63.924, which is significant at the 0.05 level $(p=0.000)$. A significant association was found between the level of willingness to switch to use public transport and the respondents' monthly income. Cramer's $V$ value showed that monthly income had a moderate relationship with the level of willingness to use public transport $(\mathrm{V}=0.408)$.

\section{Environmental Awareness}

Table 7 shows the views and opinions of respondents regarding the effects of motor vehicles on environmental issues. When respondents were asked about their knowledge of this subject, the answers from the majority of respondents indicated that they knew about ozone depletion, acid rain, oil spills, noise pollution, air pollution, and the greenhouse effect. This result indicates that the majority of respondents were aware of the impact of motor vehicles towards the environment. Table 7 shows that the majority of respondents agreed that motor vehicles contributed greatly towards all of the environmental issues mentioned above.

Table 7. Respondents' knowledge of motor vehicles as a cause of environmental problems

\begin{tabular}{lccccc}
\hline $\begin{array}{l}\text { Problems Caused } \\
\text { by Motor Vehicles }\end{array}$ & $\begin{array}{c}\text { Minimum } \\
\text { (very inportant cause) }\end{array}$ & $\begin{array}{c}\text { Maximum } \\
\text { (not an inportant cause) }\end{array}$ & Mean & Mode & $\begin{array}{c}\text { Std. } \\
\text { Deviation }\end{array}$ \\
\hline OzoneDepletion & 1 & 8 & 2.94 & 1 & 1.851 \\
Acid Rain & 1 & 8 & 3.01 & 1 & 1.893 \\
Oil Spill & 1 & 8 & 3.23 & 1 & 2.057 \\
NoisePollution & 1 & 8 & 2.58 & 1 & 1.663 \\
Air Pollution & 1 & 8 & 2.25 & 1 & 1.470 \\
Green House & 1 & 8 & 2.94 & 1 & 1.983 \\
\hline
\end{tabular}

This result is consistent with that of several other studies. Nasrudin et.al (2014), Anable (2005), Hagman (2003), and Tertoolen et al. (1998) suggested that although information about the negative environmental effects of car usage raises some awareness, this awareness is usually insufficient to change behaviour. Even though the majority of respondents are aware of the dangers of motor vehicles on the environment, they still refuse 
to use more sustainable modes, such as walking or cycling. They also gave reasons why they were not ready to walk. Table 8 shows these reasons.

Table 8. Percentage of reasons why respondents did not like to walk

\begin{tabular}{lcc}
\hline Reasons & Total & Percentage (\%) \\
\hline Hot weather & 226 & 58.9 \\
Walking is exhausting & 202 & 52.6 \\
Walking is not safe & 156 & 40.6 \\
Driving a car is more convenient & 103 & 26.8 \\
No proper pedestrian walkways & 83 & 21.6
\end{tabular}

The majority of respondents provided negative feedback. They stated that they did not like to walk because of the hot weather. They also considered walking as "exhausting" and "not safe." They also stated that driving a car was more convenient than walking. "No proper pedestrian walkways" was also one of the reasons why they refused to walk. It was evident based on McDonald's (2008), as cited by Shokoohi et al. (2011), who believed that according to research, humans normally follow their norms in terms of travelling patterns. However, some evidence shows that the inclusion of environmental concern measures provides additional beliefs that can be targeted to change behaviour (Anable, 2005). Advertising campaigns, with the intent of increasing more sustainable transport usage, should focus on the environmental benefits of using sustainable transport by labelling walking, cycling, and public transport as environmental symbols; thus countering the status symbol of cars. For instance, if the hot weather in Malaysia becomes an excuse for people not to walk, then the development and maintenance of pedestrian lanes should be upgraded by installing covered walkways. Cycle tracks should also be developed to encourage people to use bicycles as a convenient mode of transport; especially for short trips. In targeting the needs of different population groups, policy-makers should also consider how to make public transport provide similar benefits as using a car, in order to make public transport more attractive.

\subsection{Conclusion}

This study indicates that the majority are not ready to consider cycling or walking as alternatives to using a car. A significant association exists between the level of willingness to reduce car usage and the age of respondents. The younger age group (21-30 years old) recorded the highest result for being "extremely not ready" to walk or cycle. Based on gender, men showed a relatively higher level of unwillingness than women. This study also shows similar results with previous studies, proving that women are more pro-environment than men. Male respondents were more "extremely not ready" to use public transport than female 
respondents. In terms of income, Chi-Square testing showed that monthly income had a strong relationship with the level of willingness to use public transport. The higher the income, the lower the level of willingness to use public transport.

The implementation of a sustainable transportation system cannot be achieved in a short period. Ensuring a sustainable transport campaign requires that the residents of Shah Alam, and Malaysia in general, should have mental and physical readiness. Campaigns, programs, promotions, and advertisements, regarding the importance of protecting the environment by using sustainable vehicles, should be strengthened. The campaign could be spearheaded by non-government institutions, such as public transport corporations, local authorities, health organizations, and environmental lobby groups. A coordinated approach could influence public attitudes towards car ownership and usage among the next generation of potential drivers, and contribute towards restraining the demand for car travel.

\section{Acknowledgement}

The authors would like to express our gratitude to the Ministry of Higher Education Malaysia (MOHE), Universiti Teknologi MARA (UiTM) and Universiti Kebangsaan Malaysia (UKM) for their generous contribution towards this research.

\section{References}

Anable, J., (2005). 'Complacent car addicts' or 'aspiring environmentalists'? Identifying travel behaviour segments using attitude theory. Transport Policy 12 (1), 65-78.

Curtis, C \& T. Perkins, (2006). Travel Behaviour: A Review Of Recent Literature, Impacts of Transit Led Development in a New Rail Corridor, Perth. Department of Urban and Regional Planning Curtin University.

Garling, T., Gillholm, R., E.Garling, A., (1998). Reintroducing attitude theory in travel behavior research. Transportation, 25, 129-146.

Hagman, O., (2003). Mobilizing meanings of mobility: car users' constructions of the goods and bads of car use. Transportation Research Part D, 8(1), 1-9.

Handy, S., Weston, L., Mokhtarian, P.L., (2005). Driving by choice or necessity? Transportation Research Part A, 39(2-3), 183-203.

Hiscock, R., Macintyre, S., Kearns, A., Ellaway, A., (2002). Means of transport and Ontological security: do cars provide psycho-social benefits to their users? Transportation Research Part D: Transport and Environment, 7(2), $119-135$.

Nasrudin, N., Nor, A.R.M., Noor, H.M., Abdullah, Y.A,(2013). Urban Residents' Awareness and Readiness for Sustainable Transportation. Procedia - Social and Behavioral Sciences, Volume 105, 632-643.

Nasrudin, N., Rostam, K., Noor, H.M.(2014) Barriers and Motivations for Sustainable Travel Behaviour: Shah Alam Residents' Perspectives. Procedia - Social and Behavioral Sciences, Volume 153, 510-519. 
Nasrudin, N., et.al. / Asian Journal of Behavioural Studies (AjBeS), 3(11) May / Jun 2018 (p.137-146)

Nilsson, M., Kuller, R., (2000). Travel behavior and environmental concern. Transportation Research Part D, 5, 211-234.

Polk, M. ,(2003). Are women potentially more accommodating than men to a sustainable transportation system in Sweden? Transportation Research Part D: Transport and Environment, 8(2), 75-95.

Polk, M., (2004). The influence of gender on daily car use and on willingness to reduce car use in Sweden. Journal of Transport Geography, (12 ), 185-195.

Shokoohi R., Hanif N.R., Md Dali M. (2011). Children Walking to and from School in Tehran: Asociations with neighbourhood safety, parental concerns and children's perceptions. Asian Journal of Environment-Behaviour Studies, 2(4).

Stern, P., (2000). Toward a coherent theory of environmentally significant behavior. Journal of Social Issues 56 (3), 407-424.

Tertoolen, G., Van Kreveld, D., Verstraten, B., (1998). Psychological resistance against attempts to reduce private car use. Transportation Research Part A, 32(3), 171-181.

Van Vugt, M., Meertens, R., Van Lange, P., (1995). Car verses public transportation. The role of social value orientations in a real-life social dilemma. Journal of Applied Social Psychology, 25, 258-278.

Van Liere, Kent and Riley Dunlap ,(1981).Environmental concern: does it make a difference how it's measured?, Environment and Behaviour, 13. 